\section{Bertold Brecht - Exile, image and Utopia}

Quote: SOUSA, Edson Luiz André de; PEREIRA, Márcio Fransen. Bertold Brecht - Exile, Image and Uutopia. Porto Arte: Revista de Artes Visuais. Porto Alegre: PPGAV-UFRGS, v. 22, n. 36, p.1-12, jan.-jun. 2017. e-ISSN 2179-8001. DOI: http://dx.doi.org/10.22456/2179-8001.80112

Translated by Ana Carolina Azevedo and Bruno Declerque

Abstract: This article is the result of a master's research carried out in the framework of studies on psychoanalysis, art and politics. It aims to make an articulation between elements of Bertolt Brecht's exile and his thought from the perspective of Fredric Jameson, in the book Brecht and Method (2013). Therefore, it was necessary to bring into the discussion a production from Brecht's exile - titled Kriegsfibel.

Keywords: Arts. Theater. Art theory and criticism. Bertolt Brecht. Exile. Fredric Jameson.

"let nothing be called natural, lest all things be held unalterable.

Bertold Brecht

Thinking about Brecht, nowadays, requires more than an adaptation of his dramaturgy to the present day. Fredric Jameson, in the book Brecht and Method (2013), performs a fundamental part of this work (to rethink Brecht) through a complex course that invigorates his ideas - as Gislaine Cristina de Oliveira (2011) points out, in relation to Jameson. The author, already in the prologue of the book, shows himself as willing to "embrace" (p.1) Brecht "in his multiplicity in a dialectical manner and to cross his dispersion 'towards a certain unicity"'(p.23). This is no small thing, since Jameson reads, in Brecht, what is "totalizing", or, what makes Brecht a certain whole.

Jameson originally published Brecht and Method in 1998. The book was translated into Portuguese "on the German playwright's birthday centennial celebrations" to A questão do Método de Brecht, which occurred in the following year, 1999. The group of translators was composed by intellectuals concerned with the "(re) placement of some important beacons to think about Brecht's theater" (OLIVEIRA, 2011, p.1-3). It is interesting to note that a similar movement had occurred with Roland Barthes in the earliest plays, in Paris, of Brecht's plays in the early fifties.

In 1965, Roland Barthes (2007) wrote an essay entitled I've always liked the Theater, and, as in other texts, it brings a critique to the passage of the Berliner Ensemble through Paris in those years. It happens that Barthes identified a "Brechtian distinction" that was not so obvious to be perceived and put it at the level of a "code" for the time. And still, going even further, he gave this distinction the status of a "phantasmatic" and "utopian" order. It is possible to perceive that Barthes, in this essay, proposes more than a matter of taste for the French public. In attempting to describe his astonishment, Barthes writes: "not a refinement of colors or a plastic of movements (one can find them in other contemporaries), but a 'code', so clear and so sober that the spectacle becomes at the same time dazzling and tense" (BARTHES, 2007, p.7).

For Barthes, the playwright solves the contradiction, insoluble till then, of "making art accessible and difficult at the same time" (p.8). Barthes argues that by unraveling the abuses of the rules, that is, through the very economic structure of theater, training and crafts, that Brecht escapes, and thus, formulates something that could be called new for the time. After Barthes, the broader development of these issues was handled by Jameson, in his Brecht and Method - in our opinion. We recall here that Walter Benjamin (1985), in his essay The Author as Producer, develops an analysis of authors and their productions in the society of their time. The focus of Benjamin's analysis was to draw a distinction between authors who supply the dominant structure and those who produce new forms from new techniques. For Benjamin, the author is a producer when he operates in the machinery of a literary structure, the essayist gives - among other examples - Brecht as an author who moves the machinery of theater, especially by having imprinted in his dramaturgy new techniques that have transformed the structure of production and the place of theatrical reception. In questioning the fourth wall of theater, the division between stage and audience, Brecht also questioned the limits between actors, directors, characters and, above all, the function of a new modern theater. In the words of Walter Benjamin,

A writer who does not teach other writers teaches no one. The modeling character of the production is, therefore, decisive: first, it must guide other producers in its production, and secondly, it must provide a more perfect apparatus. This apparatus is all the better the more it leads consumers to the sphere of production, that is, the greater its ability to turn the readers or spectators into collaborators. We already have a model of this kind, which I can only speak of here briefly. It is the epic theatre of Brecht (BENJAMIN, 1985, p.132). 
Jameson (2013), throughout the book Brecht and Method, throws himself on the field drawn by the playwright in the light of modernity, throughout the first part of the $20^{\text {th }}$ century,. During his course, Jameson maps out three dimensions - thought, language, and narrative - which, in turn, elaborate a triangulation of somewhat imprecise and separate tracings, but which, when linked together, show the reader the most Brechtian side of Brecht. The certainty regarding the imprecision of Jameson's tracings can not be disregarded, since it is the author who presents them as "triangulations with Brecht": "it seems that the distinctive and unmistakable trait of Brecht's work can only be described in dubious categories, especially those related to style, ideas and plot" (JAMESON, 2013, p.39). Thus, such triangulation is not conclusive, but methodological for an advance on the studies on Brecht. The triangulation involves a single visible trait in three dimensions - thought, language and narrative - that do not prioritize each other but project each other to the other two. Brecht's distinctive method can only be discussed, for Jameson, with the tensions of these three dimensions which are, consequently, characterized as transient.

It is important to say that Brecht had one of the most productive exiles of the first part of the $20^{\text {th }}$ century. In April 1941, Brecht was exiled in Finland. In that note, the playwright explains that the constant border crossings imposed during his exile were not, for him, his family and collaborators, only an exercise of losses (which is very possible to be imagined for us with the frequent changes of country they made), but also an exercise of choices of what always seemed more essential to carry alongside them. It is as if the taste of the collector was imposed on the exile, especially Brecht, collecting here and there, nothing more and nothing less, what he really needs to go on with his work and, why not, with his survival. Ruth Berlau, actress and Brecht's collaborator, writes her memoirs about 25 years after the playwright's death and, in the fourth part of her book, recalls, under the title Swapping Countries as if Swapping Sandals, that:

When Brecht left Germany, he did not expect the Nazi regime to last long. For this reason, he tries to establish himself well near the German border, so that he could return quickly (BERLAU, 1985, p.74).

In 1933, with the rise of Nazism, Brecht travels, like many of his time, European countries in search of refuge, having spent fifteen years in exile until his return to Berlin in 1955. George Didi-Huberman (2008), in the book Confronting Images, cites the places where the playwright spent his time in exile. According to the author,

Brecht's exile began on February $28^{\text {th }}, 1933$, the day after the Reichstag fire. From that moment on, he traveled from Prague to Paris, from London to Moscow, settled in Svendborg (Denmark), went through Stockholm, arrived in Finland, quickly went to Leningrad, Moscow and Vladivostok, settled in Los Angeles, spent some time in New York, left the United States (...) returned to Zurich before finally settling in Berlin (DIDI-HUBERMAN, 2008, p.13).

Part of Brecht's production from his time in exile has the characteristic of clipping and collage of photographs that bring the image of the wounded or, in most cases, the corpses of the war, producing a kind of book-atlas. The book was titled Kriegsfibel. The Kriegsfibel ${ }^{1}$ edition, from Ediciones del Caracol, published in 2004, is the one we use in the master's research. It is based on the German edition from the 1994's Eulenspiegel Verlag, which is a reproduction of the first edition, from 1955. The editions bring, just below each photograph and its original caption, a small four-line epigrammatic poem - which literally means "overwriting". The poems, often ironic, seek to cause a shock to the photographic image. Each photo-poem set is called a card or photo-epigram. On June $20^{\text {th }}, 1944$, Brecht writes in his Work Journals:

Working on a new series of photoepigrams, I look at the old ones, which partly date from the beginning of the war, and I am convinced that there is almost nothing to be cut out (politically nothing), which is proof of the validity of my point of view, given the extremely changeable aspect of the war (BRECHT, 2005, p.230).

The organization of the War Primer recalls Brecht's Work Journals, which were written between 1938 and 1955. The "journals" are records from his work while in exile and were assembled with brief texts, but with far fewer images than the War Primer. In cards 10 (fig. 01) and 45 (fig. 02) from the book we face a graveyard. Placing these two cards side by side, reveals us a sequence of crosses embedded in the ground that mark the presence of pits. Card 45 is highlighted by the central cross in which a glove (fixed in the wood) faces the sky. Card 10 , being more solid and direct, carries the inscription of a word: "Unknown". Didi-Huberman (2008) writes that there is a funereal consciousness of political evil in the images collected by Brecht and the same epigrammatic poems are the ones that convey a funeral conscience - a posture that faces death - which is done on purpose, in Brecht.

1. From now on, we will refer to Kriegsfibel through a free translation: War Primer. 


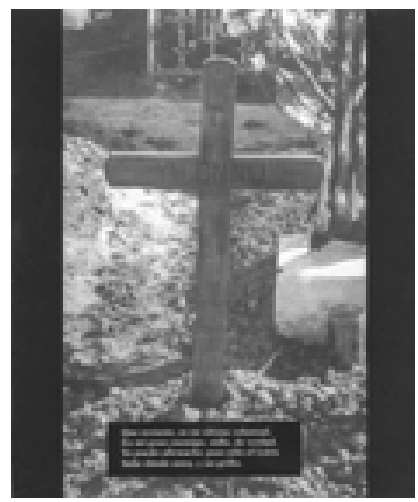

Figure 1. Attachment A - Card 10. Source: Brecht, Bertolt. [Kriegsfibel] $A B C$ de la guerra. Madrid. Ediciones del Caracol, 2004.

For Didi-Huberman (2008), Brecht's cards sometimes, contradict the hope. The "visual power" of the book-atlas is "accompanied by a restless, obscure and often pessimistic tone" (DIDI-HUBERMAN, 2008, p.35). Didi-Huberman makes this argument recalling that Brecht also demonstrates some regret in the clipping and pasting of these images from magazines and newspapers. In relation to the concentration and extermination camps, the playwright remains "silent, as if deprived of words or political explanations", for example. Both cards, from sometime between 1945 and 1948, are the end of World War II (DIDI-HUBERMAN, 2008, p.35-36). The Allied advance on Nazi Germany is confirmed; the playwright, who imagined a quick return home early in 1933, could now finally pack his bags. 15 years have passed. The poem on card 45 brings the following:

In school we learned of an Avenger who Would punish all injustice here on earth.

We went to kill and met with Death.

Now you must punish those whose orders sent us forth.

Returning to Jameson (2013), the idea of utility is a coherent argument for the proposal of a Brechtian thought today. This proposal raises an utopian perspective on the work of the playwright, which is only now possible to be extracted, since, more than ever, the "present market rhetoric delegitimizes left-wing discourses" (JAMESON, 2002, p.271). The evidence of this utopian Brecht would be in the inseparable relation between activity and knowledge operated in his art, which we can also judge by the very idea of an war primer. In the field of image, we take as an activity the act of seeing images or even producing an image; and, in relation to knowledge, we have in mind the thought about glancing at the image as the proposition of a thought through the legibility. That is, perceiving an image or producing an image is an activity that is not carried out without consequences and that operates in the logic of the viewer.

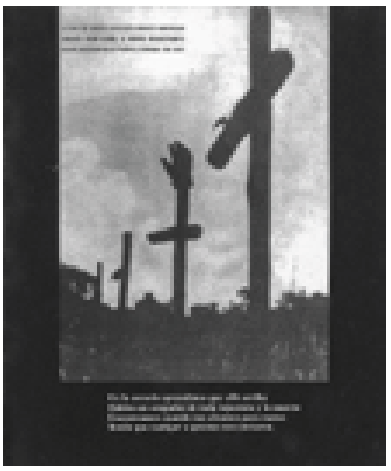

Figure 2. Attachment B - Card 45. Source: Brecht, Bertolt. [Kriegsfibel] $A B C$ de la guerra. Madrid. Ediciones del Caracol, 2004.

Jameson talks about aesthetic formation, but also about political formation. However, it is as if we say: isn't there an activity in Brecht that doesn't have a political character? Obviously not. For Jameson, Brecht's ways emphasize the understanding of the process as a purpose rather than as a "pretext-purpose" (JAMESON, 1998, p.13-14) for political thought. It turns out that, for Brecht, it is not that there is a juxtaposition between thought and activity, but rather a revolutionary activity, in the sense of the act of returning again to the middle of the action. To collect, to wait, to cross borders, to return and, finally, to return again, interrupting the actions, positioning itself in time with the two feet; it is also to walk through different perspectives. As well as in a position of exile, it is a matter of taking position, knowing that there is an "off the field" (DIDI-HUBERMAN, 2008, p.11). That is, to extrapolate barriers of the yes and the no, to activate forms of trench and of border that, at the same time, make the composition of a movement of approaching and distancing; of "approaching with reservation" and "distancing with desire" (DIDI-HUBERMAN, 2008, p.12). Thus, the Brechtian aesthetic is linked to a position of exile, in the sense that there is a constant problematization of the means of action, of the process from which one takes a position that suggests, in the end, the making of a thought that is political.

Cards 10 and 45 from the War Primer bring in the poem's writing this essentially dialectical position of Brecht, but that is also didactic. We can read the poem independent of the image it 
comments on. However, Brecht's caption does not respond; the caption is alive and in it we find all the colors that the black and white images of the book do not bring, or rather, the contrasts of the image itself in black and white. According to Jameson, "although being didactic, we must recall that Brecht, strictly speaking, never had a doctrine to teach, even when it refers to Marxism as a system" (JAMESON, 2013, p.13-14). What Jameson articulates is that Brecht's "lessons" were linked to the movement of proposals, without abolishing from them a certain ambiguity characteristic of the Brechtian dialectic. To exemplify, Jameson articulates on the sense of science in Brecht, from the play Galileo. Brecht, for the author, in relation to the sciences and knowledge, does not dissociate himself from what in a "popular manual of mechanics" can be found to be "the resulting combination of ingredients and the learning of the use of new and unusual tools" (JAMESON, 2013, p.17).

According to the author, for Brecht "science and knowledge are not arduous and tedious tasks, but, above all, primary and principal sources of pleasure" (JAMESON, 2013, p.17). For Brecht, the "learning games" are "endowed with an entertainment in which pedagogy itself becomes an element of the class represented by it" (JAMESON, 2013, p.17). And yet "the teaching of practice is also in itself a legitimate practice, and thus 'participates' in the very satisfactions provided to its apprentices" (JAMESON, 2013, p.17). Art would have, among its functions, the function of beautifying life in this childish thing that is to do things for the sake of it and, perhaps, to play thing just for the sake of it. However, it is understood as a learning process. In this case, the very "activity is one of the traits of knowledge and art insofar as they flow back into the useful" (JAMESON, 2013, p.17). Activity is inherent in the slow "process in which usefulness becomes an purpose in itself - not a formalistic and empty purpose [...] or any purpose that we invoke to be able to keep us busy" (JAMESON, 2013, p.17). Brecht's art claims a laboratory of experimentation, in which creation is nothing other than learning processes. Brecht's art has the specificity in what, for Jamenson, "building socialism" is lost when the utopian process is concrete, because, as it approaches, what survives in Brecht as a thought - not in spite of a situation of exile, but much due to his position of exile - is a praxis of the order of the day (JAMESON, 2013 , p.17). Therefore, an activity that is always changeable and transient and never totalizing. Primarily, Brecht's specificity would be, therefore, in the transient position vis-a-vis reality, active precisely in recognizing reality as transient.

In the first part of the already quoted book by Jameson, the author, thus, breaks Brecht's thought into a framework of different layers, which at the same time relates to other layers, but which also bring with them their specificities. The first layer is the concept of "estrangement"; the second is the layer of the "autonomization" problem; and, before calling the issue of the "dualities of the subject" - fourth layer -, we have the third layer of the "Epic" as a "third person."

\section{THE EFFECT OF ESTRANGEMENT}

Jameson (2013, p.57-69) proposes that the effect of the Brechtian estrangement is currently a Brechtian concept that, to be understood, we must, first of all, strange it . Influenced by classical Chinese wisdom, Brecht compensates, for Jameson, the shortcomings of Marxism. We can associate it with something close to Foucault's criticism on Marx. For Foucault, not only social structures motivate power relations, but also the micro-relations of power that operate throughout society, in its discursive microsystems, in relationships that are not just economic. But certainly Brecht doesn't think in the same way as Foucault does. Quoting Antony Tatlow (1977), Jameson writes:

We can not say that there were no "metaphysics" or epistemology in Chinese philosophy, but these two areas - so crucial to Western philosophy - were conceived very differently. The earliest Chinese philosophers were practical humanists, concerned with social order. Apart from the human standard and a constant awareness of the social context, perhaps the most striking quality of Chinese thought is the insistence on the closest possible connection between knowledge and action (JAMESON, 2013, p.58).

Jameson traces the influence of "classical Chinese wisdom" on Brecht's thought through a domain commonly associated with Machiavelli and Lenin. But it turns out that, according to Jameson (2013, p.58), Brecht's emphasis does not depart from the "mastery of an individual ethic". The specificity of the Brechtian thought, which is investigated between the classical and the modern, becomes clearer when the question of the social role appears in Jameson's reading. Still based on Tatlow, the author takes up the notion of "Haltung - posture" as a philosophical category of transmission of teachings (JAMESON, 2013, p.58). We propose to exemplify the Brechtian position from the War Primer.

Card 47 (fig. 03) has the following description on its previous 
page: "An American soldier looks at a Japanese soldier who has just been forced to kill. The Japanese soldier had hidden in a boat and fired at the American troops "(BRECHT, 2004, p.106). For Didi-Huberman, card 47 is like a document that serves two truths. "The observer [of the card] sees the triumph over the Japan allied to Hitler", yet there is yet another deeper truth: "the American soldier is the instrument of a colonial power fighting against another colonial power" (BRECHT, 2004, p.41). By inducing the reading of the image, Brecht instigates the observer to be an engaged spectator to what is double, or multiple, in the image. In the case of card 47, the epigram is as follows:

A beach was obliged to dye itself red with blood. It belonged to neither of them.

They were, so it is said, forced to kill each other. I believe it, I believe it. I just want to ask: By whom?

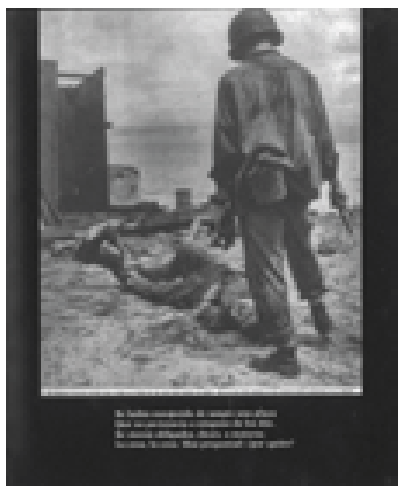

Figure 3. Attachment C - Card 47. Source: Brecht, Bertolt. [Kriegsfibel] $A B C$ de la guerra. Madrid. Ediciones del Caracol, 2004.

Jameson reminds us that Brecht cares more about "reality" than about "realism." When the estrangement effect is one of the traces of the Brechtian thought, from Brecht's modernism, which turns to the expression of an original and historical function, of surprising varieties of forms as much as reality is capable of assuming (JAMESON, 2013).

The effect of estrangement brings with it the characteristics of the montage, to the extent that it manages to organize a great number of traces of an artistic or social practice. Beyond its function in bourgeois enlightenment, according to Jameson, the effect of estrangement must be felt as strange and it must strange the human nature itself in its universals. We now arrive at core of the Brechtian arsenal throughout the exile: the effect of estrangement that confers it a posture. In the traditional theater, bourgeois theater for the playwright, he comments (BRECHT, 2005) that emphasis was placed on a timelessness of its object. History is told in a way to suppose "universal" situations and it allows only one man, of all times and all races, to express himself. The timelessness circumscribes "eternal" answers, the topic is always the same as the answer will also come to be, there are no elements of differentiation. For Brecht, this conception does not admit a thing called History, it is only the-history, that is, some elements change, but the man remains unalterable; still in this conception, "History is a reality in regards to the environment, but it is not in relation to the human being" (BRECHT, 2005, p.85). In summary:

The environment is characteristically insignificant, it is conceived simply as a motive, it is a variable quantity, something inhuman, there is, in fact, the permanent immutable, the fixed greatness. (BRECHT, 2005, p.85).

Rosenfeld (2000) defines that the function of estrangement is to nullify itself. Making it distant nullifies the familiarity of our habitual situations to the point where it becomes "strange" to ourselves and becomes, at a higher level, this more familiar situation of ours. So, the estrangement then becomes "denial of denial; to take, through its effect, the unknown to the known" (ROSENFELD, 2000, p.152).

To make it strange is, therefore, at the same time to make it known - to take position, as Didi-Huberman (2008) confers to Brecht's exile. Rosenfeld says that the theory of estrangement is itself dialectical. In the technique in question, things exist only insofar as they are transformed, to the extent, therefore, that they are in problematization with themselves. This also applies in relation to the feelings, opinions and attitudes of men, through which the different kinds of social interactions are expressed respectively. The estrangement effect is, therefore, a return to a classicity that becomes clearer as we learn that Brecht seeks his bases in Chinese wisdom more than in Russian formalists. Brecht writes the essay Alienation Effects in Chinese Acting between the 1936 and 1937; there is a note from the Brazilian edition from 1997 that says that the production of the text was caused by a spectacle by the Chinese actor Mei Lan-fang's acting company, attended by Brecht in Moscow in 1925. There is no doubt that Brecht was greatly influenced by this performance and that it played a key role in the development of a 
Brechtian thought.

[...] the Chinese artist never acts as if there was a fourth wall beyond the three that surround him. He expresses his awareness of being observed. This immediately distinguishes him from the stage illusions from the European stage. The audience can no longer have the illusion of being an unseen spectator of an event that is really happening. An entire European technical elaboration, which helps to conceal the fact that the scene is arranged in order to facilitate the view from the audience, is therefore unnecessary. In addition, the artist observes himself. [...] An obvious look at the floor, to evaluate the space available, does not impress him because he is able to break the illusion (BRECHT, 2005, p.106).

\section{AUTONOMIZATION}

The second layer of the four that leads us to the composition of Brecht's thought, for Jameson, is the layer of autonomization. Here, Jameson takes up the narrative feature of the epic genre from Brecht's theater. We recall that, unlike the dramatic, the "narrative can be cut into several separate pieces as if it was cut with scissors" (JAMESON, 2013, p.69). Each slice assumes an independent posture, so to speak, a separate and individual attitude towards the others. The War Primer, for a time, was seen by us as a movie screen in which many images were paused and only linked because they were in the same book, or the images in Brecht and Berlau's book dealt with war etc.; but in fact this association does not need to be totally discarded, perhaps just resized. The autonomization of Jameson's reading allowed us to sustain not the reference of the film (no matter how much Brecht is associated to Chaplin's films), but rather the image of a man holding an old camera that records, here and there, its own course. In the case of the War Primer, the trajectory is as follows:

First we can notice the Spanish War through the details of a Basque beach and the Plaza de Catalunya in Barcelona, occupied by General Yagüe. There are also lines of war tanks invading Poland, the burning Norwegian sky, the entry of German troops into the Netherlands, Belgium, and France. It is possible to notice Roubaix destroyed, Paris under occupation, a French man from the resistance shot by the Nazis. It is possible to notice how the war is understood and soon Singapore, Siam, New Guinea and other islands of the Pacific, Palestine, Sicily, Italy, Normandy, the front of battle is again [...] It is finally possible to notice, at the time of the release, how survivors find their houses devastated or rejoice when meeting other survivors; how the German prisoners wander aimlessly, exhausted, slaughtered like frozen ghosts; how everything is destroyed and how, above all, they enjoy returning to their lives (DIDI-HUBERMAN, 2008, p.55).

Through photographic representation, Brecht did not need to be physically on the battlefield in order to "witness" the history - the course of the War Primer does not coincide with the trajectory of exile and change of countries already cited. Brecht was a great spectator of the war; the position of exile he obtained was also a narrative of his own situation. During his exile, his concept of estrangement came to tell him: look carefully. This carefullness, primarily, produces interruptions, as well as a divisibility of a process that has been established in an entity of "objetification. It is not only the seeing, but also thinking about the position by which one looks. It is, within the art, a violence that is revolutionary, utopian, to strange forms and to survive them as a spectator, especially, when embedding, in the concept of spectator, the characteristic of the Brechtian actor who does not metamorphose completely with his character, but who is required to do so in the game that presupposes incomplete metamorphoses between themselves and what is represented - in the case of the spectator, what is recreated when looking.

\section{EPIC}

The third layer of Brecht's thought, according to Jameson (2013), is the epic or the third-person function. With a parity between epic and the notion of the third person, Jameson emphasizes the primacy of the narrative style over the dramatic in Brecht's work as a factor that is also linked to the "distant being" and "interruption of action" of the previous layers, through the estrangement effect. As pointed out, through Didi-Huberman (2008), in Brecht's position of exile there is an approximation to war, an exposition of war that, at the same time, is a knowledge, a position that stands as a writing of exile, an absolutely aesthetic work of the artist on the battlefield that was full of uncertainties about the future. In this way, the narrative of exile, through the images and poems of the War Primer, also exposed the situation around. Card 42 (fig. 04) shows a frightened Thai girl hiding in an improvised trench. This photo was cropped by Brecht; it is the cover of the magazine LIFE, from March $17^{\text {th }}, 1941$. And the epigram written below the image reads as follows: 
That it he not discovered and killed

For in the air is the Lord's wrath The people crawled fearfully in the earth And she followed the battle from afar

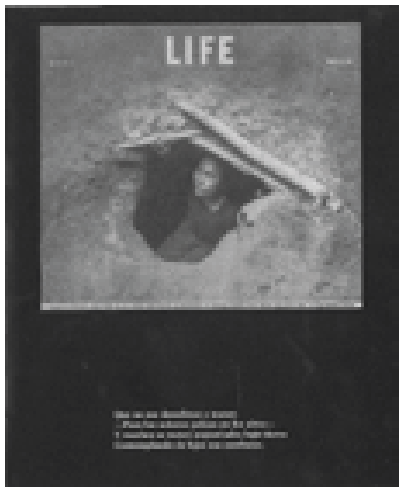

Figure 4. Attachment D - Card 42. Source: Brecht, Bertolt. [Kriegsfibel] $A B C$ de la guerra. Madrid. Ediciones del Caracol, 2004.

It is correct to say that the War Primer is a document about a period of great wars, however, in handling it, one can see that in there any non-linear choice in disposing things shows at least two planes. What is enunciated gives the reader an improvised shelter, of a dialectical character, which does not establish itself as a terror or pity, it triggers it to take position when perceiving at least two poles of war, to move by these poles and reflect on what you see. This even seems to be the function of cards like 21 (fig. 05), to make a trench, a barrier to blind identification with what is in sight. Card 21 carries the image of columns of smoke rising from the ground, preventing debris or those seeking to protect themselves on the ground from being seen. Here is a "breath of dust on the face" that Brecht now produces for the spectators. The epigraph written by Brecht reads as follows:

A cloud of smoke told us they were here They were the sons of the fire, not of the lights They came from where? They came out of the darkness Where did they go? Into eternal night.

We also bring one of the elements that stands out in these two cards; it is the airplane object with its two powers: the destructive and the utopian. In the journal's records from August 28th, 1940 (figure 6), Brecht writes that there was in his day an impossibility of making a poetry of objects, for when he had gone to Sweden before the war, he had proposed a film with the motto
" The airplane for young workers" - a weapon in reliable hands -, he writes, even if he only wanted to give expression to the dream of flying, man's basic dream. However, an objection soon came: "you certainly do not want them to be bomber pilots" (BRECHT, 2005, p.116). The image literally cut and pasted next to the text, on the sheet of his journal, is that of a warplane panel, which stands out as a cluster of connections that sustains the deadliest war in the air, as well as the possibility of crossing borders and envision a future.

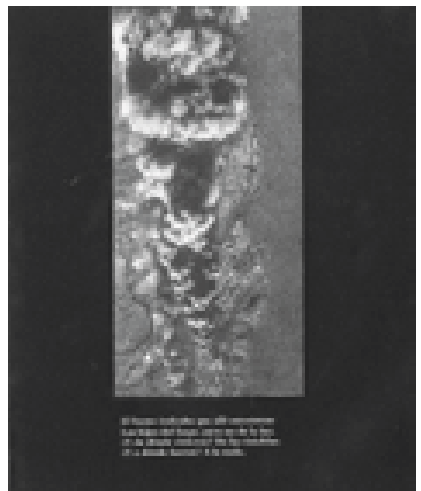

Figure 5. Attachment E - Card 21. Source: Brecht, Bertolt. [Kriegsfibel] $A B C$ de la guerra. Madrid. Ediciones del Caracol, 2004.

Here the sky can not be seen from below or from above: either by the man on the plane, or by the man who shelters himself on the ground. In the Brechtian sense, if we may say so, the sky sustains a historical landscape in which elements such as the plane and the frontier show the situation of man in the social gear, sometimes unable to create new connections, his own crossings and escapes.

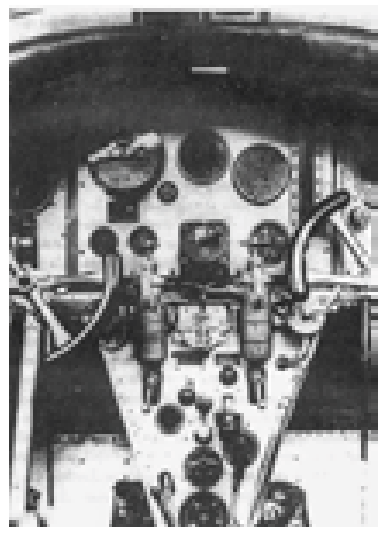

Figure 6. Attachment F. Source: Brecht, Bertolt. [Kriegsfibel] $A B C$ de la guerra. Madrid. Ediciones del Caracol, 2004 
In Brecht, exile acquires a status of thought, of articulation between knowledge and activity, in the extent the playwright proposes to narrate, however, his situation as if he were working with a character. But that's not all. We have argued that Brecht as if he were a collector - prioritized collecting and carrying, along the borders, topics of his work. This was, for him, a condition almost imperative, because of the changes he constantly had to make from one country to another. Jameson's third layer, in our view, is related to this collector Brecht, especially since such a layer does not get from Brecht's thought a rejection of the 'I', or yet, a rejection of identification. The "third person" function (which characterizes Brecht's thought) translates as an impersonal knowledge and the breaking of an illusion concerning the forms that are proposed as totalizing.

In the case of theater, character and actor, they maintain a complex relationship, measured by gaps, in which the third-person function is a device that establishes the fictional element of the situation being represented (JAMESON, 2013). In the case of a situation of exile, alternatives are used to act politically, highlighting the void that constitutes the zone of uncertainties, moreover, raising the veil between law and politics and, thus, not only identify subjects and functions, but also the gaps that indicate their incompatibilities. If we expand these propositions to Brecht's work, it can be said that his measure was

[...] less of a matter of placing a given individual in a preexisting social class, with its ideological values and specific appearances, than of transcending the dual pattern of individual and collective events (JAMESON, 2013, p.89).

In this sense, we think that Brecht's position of exile takes from his thought the specificity of problematizing individual events as engendered in historical facts, while, however, a work that needs to be produced, assembled as it is the state of things that constitutes it. Brecht narrates his exile through war; his daily work, as Didi-Huberman (2008, p.16-22) says, is a journal, but not any kind of journal.

[...] while it was said that the title Arbeitsjournal [Work Journals] was elected by Helene Weigel, Brecht's companion, to emphasize its literary character and justify the disappearance of certain more private elements - sexual or sentimental such as the writer's travels with Ruth Berlau between 1942 and 1947. But that, of course, was not essential. The notion of Arbeitsjournal [Work Journals] is in fact fully justified if we take note of the real work - in the artisanal, artistic, conceptual sense, including the Freudian psychic sense of the term - that unfolds in this extraordinary work. It is a journal where all the dimensions of the Brechtian thought are built together, even if it is to contradict it. It is a permanent work in progress, it is a work in progress of reflection and imagination, of search and encounter, of writing and of image (DIDI-HUBERMAN, 2008, p.16-17).

Brecht's journal takes place on the boundaries between private and history, between fiction and document. As a genesis of Brecht's work, his journals, for the author, did not seek an intimacy of the individual. It is more of a documentary position about the encounter of a life with its time. How can we dispense from this encounter the fictional characteristic, being that the testimony that is produced about the state of exception is a narrative.

\section{DUALITIES OF THE SUBJECT}

We have reached the fourth and final layer of Brecht's thought: dualities of the subject. Such a layer is linked to Jameson's proposal to think, in postmodernity, of a duality that is set in tension with a multiplicity and not in opposition to the latter. Jameson (2013), in relation to Brecht's dualism, understands that we can speak of affirmation or denial. Let us take as example the Brechtian dualism the play $\mathrm{He}$ Who Says Yes, He Who Says No: school operas, from 1929/1930, although this text predates exile. This didactic play deals with the subject of consent, of being in agreement. Divided into two very similar parts, the play brings the journey of a boy who, before his own death, is set to take a stand.

In the first part, He Who Says Yes, a boy asks his teacher to take him on a journey to the mountains in search of remedies for an epidemic that plagued the region. The boy was motivated by the disease that already plagued his mother. Upon receiving the authorization to accompany the group that went up the mountain, the boy says goodbye to his mother, but what he did not expect was that during the trip he would be a victim of the same disease. Facing that situation, in the middle of the journey, the teacher asks him if the group should return to the city - the teacher clarifies there is a custom that requires that the boy must state that he does not want the group to return. In the end, the boy says "yes" to the custom, asking that they throw him in the valley. With few variations (for example, the fact that no one 
speaks of the disease), the second part, He Who Says No, ends with the boy saying "no" to the custom.

According to the research from Vicente Concilio (2013), Brecht wrote the second part after receiving many criticisms regarding the first; many of them based on religious visions that for the playwright began to demand a second version that would contradict the first. It is clear that Brecht's objective was to maintain a debate and not a consensus on the theme of being in agreement - "the author establishes the dialectical process, opening up to the players the possibility of trying to solve the problem brought about by the two possible responses to the same situation "(CONCILIO, 2013, p.24). The didactic play Baden-Baden is another of Brecht's works that brings the issue of agreement, but not so explicitly the issue of duality of affirmation and denial (CONCILIO, 2013). We have the issue of the duality of the subject best seen in the didactic play The Exception and the Rule; it is even possible, through Brecht's work, to better understand what Jameson understands as a structural contradiction.

The didactic plays have a function of "making their participants active and reflective at the same time" (EWEN, 1991, p.220). In the case of The Exception and the Rule, it is a matter of experiencing violence as something right and which, strictly speaking, becomes rule in our world. Traveling through a desert in search of a newly discovered source of oil, a merchant takes with him a guide and coolie (handyman). Blinded by the desire to conquer the source as quickly as possible, the man becomes disorganized and fires his guide after a discussion. Without the guide, the merchant and coolie roam the desert, lost without finding the source of oil; in a certain moment, after getting very thirsty, the coolie offers him water with a canteen. But fearing that he was being attack, the merchant kills him.

Upon arrival in the first city, the merchant is charged with murder by the coolie's wife, however, he is acquitted of the crime. The verdict of the jury was based on the following questions: Is not it more natural for the coolie to approach the merchant to kill him? Did not the coolie seem to be the one exploited in the water distribution? Could not the coolie want to take revenge? How could the merchant know that a man who he had exploited so much would do an act of camaraderie? While the questions to be thrown (experimented) by the participants in Brecht's experiment may seem too simple, we can not fail to note that they could not be realized before 1947. In fact, before Brecht's exile, The Exception and the Rule brought "more than a tone of prophecy of things that were about to happen" (EWEN, 1991, p.238) in Germany.

Returning to Jameson, the space of didactic plays is the purest brechtian freedom of creations among the actors, in his words, it is where:

[...] a simple gesture aims not only to project what would soon be done, that is, what is being done in front of us, as well as what could not have been done, which could have become something else completely different or could have been completely omitted (JAMESON, 2013, p.90).

Let us say, then, that Brecht's didactic plays, or rather that the theatrical games of his didactic plays gain a multiplicity of experiments and gain a status of structural contradiction, especially since, in our reading, they are symbolic games that lead us to believe in a absence, or still, in a void that in advance must be fictionalized and worked from the problematic that motivates it. According to Oliveira, the layer of duplicity in Brecht's thought is written by Jameson with a very precise objective: to expose the element of the contradiction that crosses his doctrine (OLIVEIRA, 2011). We conclude, therefore, that the didactic plays are exercises of contradictions that can occur on the basis of different political and social problems.

Exile and didactic play, perhaps, can be read as two terms that contradict each other in Brecht, especially because with his departure into exile in 1933 , the project of the didactic plays - the experiments among the actors - had to give way its space, again, to the spectacle of epic character. In the precise words of Concilio (2011):

The fact is that, with Brecht's exile, the project of didactic plays, with its constant formal experimentation and controversial approach of political and social subjects, gave way to the research and formalization of his texts from the 'epic plays of spectacle', which made his dramaturgy world famous. Outside Germany, the context of left-wing organizations (trade unions, workers' corals, progressive schools and experimental music festivals) was no longer at their disposal, and the design of the didactic plays ended up in the shadow of his most famous texts (CONCILIO, 2011, p.28).

We see that in exile, the utopian purpose of the didactic plays of mixing activity and thought shifts to its position of exile. One of the final directions from the book Images in spite 
of all (2008), from Didi-Huberman, is about the idea of "dismantling the order", arranging things to be seen. The montage, or montages like the War Primer, "show us that 'things cannot be what they are [and] that it is up to us to see them in another way"' ((DIDI-HUBERMAN, 2008, p.87). That is, the use of the montage in exile leads us to see things in their unfamiliar forms, on another level of experimentation.

Returning to Maurice Blanchot's essay on Brecht, fragments of Aby Warburg's work, among others, Didi-Huberman discusses the relations between poetry and dispersion in Brecht's production in exile. In the journals, for example, Brecht jumps from one page to another bringing records of the most diverse kinds from his research, as outlined by Didi-Huberman (2008):

As we go through the Arbeitsjournal [Work Journals] we don't stop jumping from one thing to another: December $4^{\text {th }}, 1941$, for example, Brecht tells us that he offers Fritz Lang a "lucky god" from the Far East; but what appears in the next page of his journal is a Mexican figure of death. February $25^{\text {th }}, 1942$, only illustrates the collection of war donations in the US, accentuating the effect of the dispersion offered: a bunch of onions with a dead rat in a cardboard box, old shoes with a prosthetic leg. August $19^{\text {th }}, 1942$, Brecht glues in his notebook an image of Ukrainian peasants forced to be slaves by the Nazi occupants; but next to it he writes: 'around $10^{\prime}$ clock, I eat in the office the sandwiches I bring and take a sip of a Californian white wine. It's hot, but we have fans.' Exactly in this garden I can read Lucretius. 'April $29^{\text {th }}$, 1944, talks about Shakespeare alongside a document that shows the imprisonment of Yugoslav hostages by German soldiers (DIDI-HUBERMAN, 2008, p.88).

These empty spaces, digressions, associations, ruptures and contrasts bring within themselves the contradictions through each interval between the records; however, there is a common background that unites them. A background of warning between subjects and objects, perhaps, a warning of a nonsense and cruel context that perhaps could not be represented otherwise, as suggested by Didi-Huberman (2008).

Didi-Huberman directs, in Brecht's production of exile, what in the fourth layer of Jameson's book is understood by us as an expression of a time logic in Brecht's thought. The French author brings the record of August $14^{\text {th }}, 1944$ (fig. 07), in which "Brecht makes a montage of three images" (DIDI-HUBERMAN, 2008, p.89). In the first, a bishop makes the gesture of blessing; in the second, men of war study a map; and in the third image we see a Nazi "ossuary" in Russia. There are, in the montage of the three images, evidence of scattered events that occurred concomitantly. There is also a cruelty of the war exposed from a perspective regarding the coincidence in time between the three images. In this way, we are led to perceive a kind of unity that is composed by Brecht as dispersed, but also identifiable when we have images of an era, or when we propose to review these images in other organizations and orders. Above all, orders that in a disorderly way can constitute intervals of viewing, fractures in the look - disorders, therefore, that in the War Primer contradict the very idea of "primer", which presuppose a certain ordering.
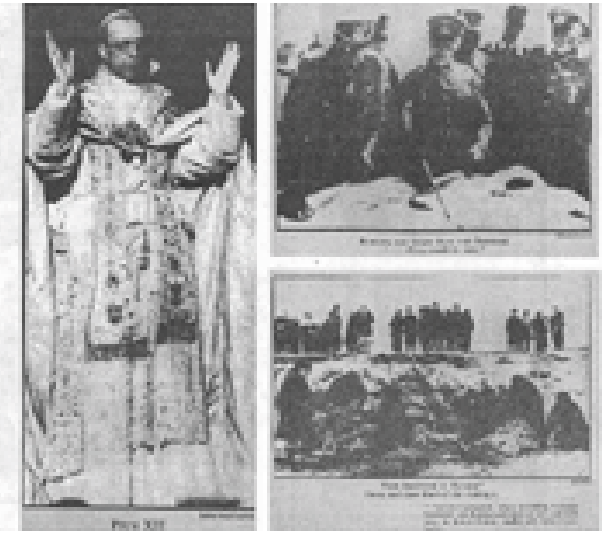

Figure 7. Attachment G. Source: Brecht, Bertolt. [Kriegsfibel] $A B C$ de la guerra. Madrid. Ediciones del Caracol, 2004.

Howard Eiland (2003, p.56), in Reception in Distraction, through the texts by Benjamin (1985), using the text What is Epic Theater? and addressing Brecht's work, writes that Brecht reinstates methods of montage. Eiland suggests that the differences between traditional and modern theater in Brecht work very much because of Brecht's montage resources: they are curves and jumps that, on stage, operate in counterpoint to the linear development determined by the evolution of the characters and the scene, leading to the next scene.

Eiland (2003) also recalls that, for Brecht, the production of epic theater insists on a radical separation of elements, which means that music and words on the stage are more independent of each other. On a theoretical level, such separation of elements seeks to make visible disparities and generate recurrent estrangement effects (EILAND, 2003, p.56). Montage means a vehicle in Brecht, which does not 
oppose dispersion. Vehicle of communication of exceptions; to convey images, the unique characteristic of the exile that occurred to Brecht. According to Didi-Huberman (2008, p.97), "there is no doubt that the montage constitutes a fundamental element of Brechtian poetry". For the author, "Brechtian poetry could almost be summed up in an art of disposing differences". The montage is in the work journals, as we have seen, it is at the origin of the war, in its form of world disorder. The montage, having its origin linked to the period of wars, questions the war in an organic way. For Didi-Huberman (2008, p.98), the trenches opened in Europe with the Great War provoked on both the aesthetics and human sciences the "decision to show by montage" - "the montage is a method of knowledge and a formal procedure born from war" (DIDI-HUBERMAN, 2008, p.98).

Firming our perception since the first conflicts of the $20^{\text {th }}$ century, the montage is consolidated as a modern method of an era in which different artists and thinkers take a stand in the aesthetic-political debate of the period of wars. Here, as well, it appears as an element of Brecht's thought that best connects the fourth layer of the subject's duality and Brecht's work in exile. In relation to Brecht, bringing Ernst Bloch, Didi-Huberman (2008) argues that the choice for photomontage, as in the War Primer, is a "subversive game of dadaist, surrealistic or 'anarchist' aspect" that does not exist "[...] without a real archaeological work destined to raise this 'unconsciousness of sight' " (DIDI-HUBERMAN, 2008, p.100). "Unconsciousness of sight" couldn't be a more precise elaboration by indicating an interpretation of what, in the productions of exile, move as formulation of the unconscious.

Therefore, the feature of montage appears in Brecht's production of exile as a mechanism of composition and symbolic dispersion of diverse roles and scenarios, whereas, also, of imagination of these same roles and scenarios in a surface of structure similar to dreams, in our analysis. In this way, Brecht's position of exile can be interpreted as a multiplicity analogous to the experimentations of didactic plays, detaching himself from a duality of the subject through a process of aesthetic manufacture and management of a production predominantly composed of discontinuities, dispersions, which has as a common ground another experimentation on the situation of being "exiled".

\section{REFERENCES}

BARTHES, Roland. Escritos sobre teatro. In: BARTHES, Roland. Sempre gostei muito de teatro. São Paulo: Martins Fontes, 2007.

Escritos sobre teatro. In: BARTHES, Roland. Por que Brecht?. São Paulo: Martins Fontes, 2007.

A câmara clara: nota sobre a fotografia. Rio de Janeiro: Nova Fronteira, 1984

BENJAMIN, Walter. Infância em Berlim. In: BENJAMIN, Walter. Rua de mão única. São Paulo: Brasiliense, 1993, p.71-142.

(Obras Escolhidas II)

Pequena história da fotografia. In: BENJAMIN, Walter. Magia e técnica, arte e política. São Paulo: Brasiliense, 1985, p.91107. (Obras Escolhidas I) 0 autor como produtor. In: BENJAMIN, Walter. Magia e técnica, arte e política. São Paulo: Brasiliense, 1985, p.120136. (Obras Escolhidas I) . Que é o Teatro Épico?. In: BENJAMIN, Walter. Magia e técnica, arte e política. São Paulo: Brasiliense, 1985, p.78-90. (Obras Escolhidas I)

BERLAU, Ruth. Ruth Berlau - Lai-Tu A amiga de Brecht. São Paulo: Brasiliense, 1985.

BLOCH, Ernst. O Princípio Esperança. Rio de Janeiro: Contraponto, 2005. 1v. O Princípio Esperança. Rio de Janeiro: Contraponto, 2006. $2 v$.

BRECHT, Bertolt. $A B C$ de la Guerra. Madrid: Ediciones del Caracol, 2004 Diário de Trabalho - 1938-1941. Rio de janeiro: Rocco, 2005. $1 \mathrm{v}$

Diário de Trabalho - 1941-1947. Rio de janeiro: Rocco, 2005. 2v.

. Escritos sobre teatro. Rio de Janeiro: Nova Fronteira, 2005.

CONCILIO, Vicente. BadenBaden. Modelo de ação e encenação em processo com a Peça Didática de Bertolt Brecht. São Paulo: V. Concilio, 2013.

DIDI-HUBERMAN, Georges. Cuando las imágenes tomam posición. Madrid: A. Machado Libros, 2008.

EILAND, Howard. Reception in Distraction. Boundary 2, v. 30, n. 1, p.51-66, 2003.

EWEN, Frederic. Bertolt Brecht: sua vida, sua arte, seu tempo. São Paulo: Globo, 1991.

FOUCAULT, Michael. Isso não é cachimbo. Rio de Janeiro: Paz e Terra, 1988. 
JAMESON, Fredric. Brecht e a questão de método. São Paulo:

Cosay Naify, 2013.

. Marxismo e forma: teorias dialéticas da literatura no século XX. Editora HUCITEC, 1985.

Pós-Modernismo - A Lógica Cultural do capitalismo tardio. São Paulo: Ática, 2002.

OLIVEIRA, Gislaine Cristina. Desemaranhar: estudo de 0 método

Brecht de Fredric Jameson. Campinhas/SP: [s.n.], 2011.

ROSENFELD, Anatol. O Teatro Épico. São Paulo: Perspectiva, 2010.

TATLOW, Antony. The Mask of Evil. Bern: Peter Lang, 1977.

Edson Luiz André de Sousa: Full professor at UFRGS psychology institute, department of psychoanalysis and psychopatology. Professor of psychoanalysis - clinic and culture at PPG. Post doctoral and PhD at the university of Paris VII, post doctoral at Ecole des Hautes Etudes en Sciences Sociales (EHESS). Researcher at CNPQ. Coordinator at LAPPAP/UFRGS (research laboratory of psychoanalysis, art and politics). Author of, among others, "Uma Intervenção da Utopia" (in English, An Intervention of Utopia), Lumme Editora, São Paulo.

Márcio Fransen Pereira: Psychologist, expertise in clinical care with emphasis in psychoanalysis (CAP/UFRGS), Master in social and institutional psychology (PPGPSI/UFRGS). Member of LAPPAP/UFRGS (research laboratory of psychoanalysis, art and politics). Social technician at specialized reference center for social assistance (CREAS/NH).

(*) This text was submitted in July 2014 and updated in 2017 for this publication. 